\title{
PENINGKATAN IMUNITAS MASYARAKAT DALAM MELAWAN PANDEMI COVID-19 MELALUI GERAKAN SELEKTIVITAS "JURNALISME HARAPAN" PADA MEDIA DARING LOKAL DAN MEDIA SOSIAL DI WILAYAH KOTA KENDARI
}

1 Marsia Sumule Genggong, ${ }^{2}$ Aswan Zanynu, ${ }^{3}$ Erni Qomariah, ${ }^{4}$ Sutyana Fachrudin, 5 Hasryani Amin

${ }^{12345}$ Fakultas Ilmu Sosial dan IImu politik, Universitas Halu Oleo

Marsia Sumule Genggong: anak kendari@yahoo.com

Jl. HEA Mokodompit, Kampus Bumi Tridharma Anduonohu, Kendari 93232

\section{RINGKASAN}

Dalam situasi pandemi saat ini ketergantungan terhadap media sangat tinggi. Media masssa dan media sosial menjadi alat yang paling dicari sebagai pengganti keterbatasan dalam berkomunikasi face to face. Orang dapat mengetahui situasi saat ini melalui kecanggihan teknologi media dan informasi. Setiap orang dengan kekhawatiran dan kecermasan dan keingintahuan yang tinggi akibat virus corona berlomba-lomba mencari informasi yang tercepat dan terkini. Namun seringkali dalam situasi ini masih banyak karya-karya jurnalistik ataupun opini yang menambah kekhwatiran yang berdampak pada imunitas tubuh manusia. Padahal semestinya media dalam bentuk karya jurnalisme hendaknya menjadi "jurnalisme harapan" yang dapat memberikan perasaan positive, tenang, damai dan memberikan harapan bahwa pandemi virus covid-19 ini akan dapat teratasi dan kita semua akan kembali hidup dalam keadaan sehat dan tenang. Dan bahwa pemerintah bersama dengan segenap komponen masyarakat bekerjasama untuk dapat mengatasi pandemi covid-19 ini. Olehnya itu melalui kegiatan KKN Tematik ini. TIM akan memberikan pemahaman sekaligus keterampilan kepada masyarakat yang diwakilkan dalam bentuk kelompok/grup masyarakat yang beranggotakan masyarakat serta pemuda agar berperan serta aktif melakukan seleksi berita atau informasi yang bersifat positif "jurnalisme harapan" yang nantinya berita tersebut akan diteruskan kepada masyarakat sekitar. Artinya dengan keterampilan data dan keahlian yang diberikan kepada masyarakat untuk melakukan proses seleksi informasi/berita akan membuat kondisi lebih baik untuk memutus rantai penyebaran pandemi covid-19. Hasil kegiatan pengabdian terintegrasi KKN Tematik tahun 2020 ini memberikan beberapa out put/luaran yang bermanfaat bagi masyarakat disaat kondisi pandemic covid-19 yakni terbentuknya grup media sosial Whats App yang bermanfaat dalam menampung beragam informasi bernilai positif untuk meningkatkan imunitas masyarakat dalam mengahadapi virus covid-19. Sekaligus memberikan pengetahuan selektifitas kepada masyarakat mengenai informasi yang benar dan informasi hoax yang beredar di media sosial. Kegiatan ini juga memberikan pengetahuan literasi kepada masyarakat agar secara proaktif memilah dan memilih informasi yang berkualitas pada media sosial dan media massa.

Kata kunci: Imunitas; Covid-19; Gerakan Selektivitas; Jurnalisme Harapan. 


\section{A. Analisis Situasi}

Di tengah pandemi virus covid-19 kekuatan yang dimiliki oleh mediamassa khususnya media on line serta media sosial lainnya sangat memberikan gambaran yang signifikan khususnya dalam memberikan pengaruh terhadap pengetahuan sekaligus dalam perilaku. Kecemasan sekaligus kekhawatiran yang tidak terkendali terlihat dari masyarakat yang terpapar informasi terutama dalam grup media sosial dan media on line. Kemudahan dan kecanggihan teknologi komunikasi menyebabkan semua informasi mengenai virus Covid-19 dalam berbagai aspek yang melanda Negara Indonesia dan dunia dalam skala luas dapat segera diakses oleh masyarakat dengancepat.

Disisi lain banyaknya waktu longgaruntuk berada di rumah yang diberikan pemerintah sebagai kebijakan untuk memutus persebaran virus covid - 19 memberikan kesempatan besar kepada berbagai media baik media on line dan grup media sosial melaksanakan misinya memberikan informasi seputar perkembangan virus covid 19 . Sayang sekali dalam situasi yang kurang menguntungkan ini kebanyakan media dan juga dalam grup media sosial misalnya Whats App, Instagram dan Face Book conten atau isi informasinya cenderung memberikan "jurnalisme virus" atau informasi yang memberikan kekhawatiran dan kecemasan bahkan "paranoid" pada masyarakat. Terlebih lagi pengetahuan yang kita dapatkan bahwa virus covid-19 belum ditemukan obat penangkalnya dan wujudnya yang tidakterlihat.

Berbagai opini pakar kesehatan menyatakan bahwa semakin banyak stimulant atau rangsangan dari luar yang bersifat positif maka akan meningkatkan kesehatan jiwa sekaligus jasmani manusia. Dalam kondisi saat pandemic covid-19 ini dimana dengan tubuh yang sehat yang ditandai oleh imunitas yang tinggi atau disistilahkan sebagi daya tahan tubuh yang kuat maka virus covid-19 akan sulit untuk menyentuh tubuh jasmani manusia. Akan tetapi sebaliknya jika senantiasa memperoleh rangsangan atau st imulan informasi yang bersifat negative akan menurunkan imunitas tubuh karena kejiwaan yang kurang sehat. Sehinga mudah terserangpenyakit.

Sebagian besar masyarakat saat pandemic virus covid-19 ini mengkonsumsi "jurnalisme virus" yakni informasi yang lebih banyak memberitakan perkembangan 
jumlah yang positif corona, Pasian Dalam Pengawasan (PDP), dan Orang Dalam Pemantauan (ODP), kelangkaan Alat Pelindung Diri (APD) dan masker, serta emosi warga yang menolak pemakaman jenazah positif corona. Belum lagi di mediasosial kita terpapar oleh gambar, video dan pernyaataan yang cenderung tanpa disadari sangat mungkin berakibat masifnya trauma dan menambah beban derita masyarakat.

Padahal saat ini ditengah wabah pandemic virus covid-19 mestinyamedia menjadi ujung tombak "jurnalisme harapan". Fungsi control pada mediaterutamamedia elektronik, juga media on line dan media sosial seharusnya lebihmengemuka.

Berdasarkan Pedoman Perilaku Penyiaran dan Standar Program Siaran (P3 dan SPS) tahun 2012 menyatakan dan mengatur bahwa program siaran jurnalistik yang dihasilkan oleh media massa dalam berbagai bentuk karakteristik mediadalam peliputan bencana atau musibah wajib mepertimbangkan proses pemulihan korban,keluarga dan atau masyarakat yang terkena bencana atau musibah. Dalam pasal 50 ditegaskan program siaran jurnalistik tentang peliputan bencana atau musibah dilarang menambah penderitaan

atautraumakeluargakorbandanmasyarakat,namunkadanghaltersebutdiabaikan.

Harapannya adalah media apapun itu apabila mengedepankan "jurnalisme harapan". Jika kondisi ini terlaksana secara serempak oleh berbagai mediayang menumbuhkan harapan maka secara otomatis masyarakat akan kompak bangkit untuk melawan virus covid -19 karena pengaruh memiliki harapan akan berdampak pada meningkatnya imunitas tubuh sehingga dalam kondisi kuat dan sehat tersebut akan sulit terpapar oleh virus. Dan secara signifikan akan berdampak pada jumlah orang yang terpapar virus semakin berkurang karena kepatuhan pada upaya mengurangi dan mengatasi penyebaran virus covid-19. Serta dampaknya harapan yang tumbuh pesat untuk melawan virus covid 19 dari rumah bisa menjadi sangatdahsyat.

\section{Program Kerja}

Permasalahan yakni menurunnya imunitas tubuh masyarakat dapat menjadikan tubuh mereka rentan untuk terpapar virus covid 19. Berdasarkan pengetahuan kesehatan 
sederhana yang dimiliki bahwa imunitas tubuh tidak hanya diperoleh dari makanan jasmani namun juga dapat dilengkapi dengan rohani, jiwa yang sehat. Dengan kata lain dalam jiwa yang sehat terdapat jasmani yang kuat. Oleh karena hendaknya berita atau informasi yang kita dapatkan dapat memberikan stimulant positif atau memberikan harapan akan kondisi yang akan membaik di tengah perjuangan melawan pandemic virus covid19.

Solusi yang dapat ditawarkan yakni memberikan pengetahuan dan pemahaman tentang jurnalisme harapan dan proses selektivitas yang harus dilakukan guna menyaring informasi yang disampaikan media daring dan media sosial dalam upaya meningkatkan imunitas tubuh guna memutus rantai persebaran virus covid19.

Kontribusi mendasar pada khalayak sasaran yakni membentuk kolompok/grup pada kelompok masyarakat sasaran (Karang Taruna) yang memiliki kecakapan dan keterampilan dalam mengaplikasikan mediadaring/media sosial sertamampumenyeleksi informasi yang bersifat positif guna diteruskan kepada masyarakat sekitar sehingga lebih banyak informasi yang positif yang diperolah masyarakat.

Adapun Program Kerja Utama yang akan dilakukan sesuai dengan Target dan Luaran yang akan dicapai yakni:

1. Pengumpulan nomor handphone WhatsApp masyarakat khususnya Karang Taruna yang ada di Desa/Kelurahan Kota Kendari dan membentuk grup media sosial di wilayah/kelurahan tersebut.

2. Membuat dan menyebarkan kuesioner untuk mengukur tingkat pemahaman dan pengetahuan, sikap dan tindakan masyarakat terkait pandemi covid-19.

3. Melakukan sosialisasi secara langsung yang dirangkaikan dengan pembagian masker kepada masyarakat di wilayah seputar RT dengan tetap mematuhi protokol kesehatan dan juga secara face to face dan door to door kerumah warga, dan juga menyebarkan brosur/pamflet ke fasilitas umum seperti masjid, kantor kelurahan dsb. 
4. Melakukan Sosialisasi secara tidak langsung dengan menggunakan media sosial Whatsapp (Group yang sudah dibentuk), media sosial Instgaram dan Facebook yang dibuat untuk mempermudah menyebarkan informasi positif kepada masyarakat.

5.Pembuatan Tempat Cuci Tangan didepan Kantor Desa/Kelurahan.

2. Tujuan dan Manfaat Kegiatan

Tujuan kegiatan pengabdian ini adalah membentuk grup media sosial yang anggotanya adalah segenap komponen masyarakat yang nantinya menjadi admin atau penyalur dalam memilih serta menyeleksi informasi positif yang akan diteruskan kepada masyarakat setenpat.

Manfaat Kegiatan pengabdian ini yakni meningkatkan imunitas masyarakat dalam menghadapi pandemic covid 19 melalui upaya penyeleksian informasi dan berita yang bersumber dari media sosial dan media massa lainnya yang bersifat positif dan memiliki kemampuan untuk meliterasi content media .

3. Luaran Pengabdian

Target Luaran yang diharapkan dari kegiatan ini antara lain:

1. Terbentuknya grup media sosial masyarakat bertugas untuk melakukan selektivitas informasi khususnya yang bersifat informasi positive yang nantinya akan dibagi kepada masyarakat setenpat secaraluas.

2. Masyarakat dapat membedakan informasi yang bersifat membangun atau memberikan harapan dalam menangkal penyebaran virus pandemic covid19 dengan lebih baik danbijaksana.

3. Mitra Kegiatan yakni media daring lokal yakni Sultra Kini, Zona Sultra memiliki kapasitas dalam berpartisipasi secara lebih baik berdasarkan bidangnya untuk secara bersama menangkal pandemic virus covid-19. 
Kegiatan ini diharapkan dapat memberikan semangat positif kepada masyarakat yang akan menambah imunitas tubuh mereka dari sisi jasmani dan rohani sehingga dapat berperan serta memutus rantai persebaran virus Covid-19.

Rencana luaran yakni Dokumen literasi informasi berupa materi, gambar, video kegiatan akan disajikan dalam bentuk buku laporan, copy $C D$, publikasi media massa/sosial, serta jurnal ilmiah relevan.

\section{A. METODE PELAKSANAAN}

MetodePelaksanaan. MetodePelaksanaanmemuathal-halberikut: (1) Tempat dan Waktu (Uraikanlokasikegiatan dan waktupelaksanaan.

Jikamemungkinkandisertai peta ataugambarlokasilainnya), (2)

KerangkaPemecahanMasalah (2) Khalayaksararan/Mitra Kegiatan

(Uraikansiapa dan bagaimanacaramenentukannya), (3)

RealisasiPemecahanMasalah(contoh: UraiakanPersiapan, penyuluhan, pelatihan, pendampingan, demonstrasi, dII), (4) IndikatorKeberhasilan (Uraiakanindikator yang akandicapaidalamkegiatanpengabdian), (5) MetodeEvaluasi

(Uraikanteknikmelakukanevaluasiuntukmengukurketercapaianindikatorkeber hasilan

1. Persiapan

Pelaksanaan kegiatan pengabdian masyarakat dan kuliah kerja nyata ini akan dilakukan beberapa tahap, yakni :

1. TahapPertama

Tahap pertama dimana team pengabdian mulai mengurus perizinan secara administratif kepada pemerintah daerah mulai Camat, lurah/desa hingga ketua RT/RW setempat. Perizinan ini bersifat pemberitahuan tertulis sekaligus meminta kesediaan lembaga mitra yang dapat terlibat dalam kegiatan serta informasi 
kegiatan yang akan dilaksanakan. Tahapan ini juga termasuk pembekalan dan sosialisasi program, penandatangan kontrak kerja dari LPPM Universitas HaluOleo.

2. TahapKedua

Pada tahap ini, tim merekrut peserta yang terdiri dari mahasiswa berjumlah 23 orang, dengan kriteria memiliki IPK 3.00 keatas, dan memiliki kecakapan khusus pada literasi informasi dalam berbagai media. Peserta yang terpilih sekaligus akan menjadi fasilitator kegiatan bagi mitra yang telah ditetapkan dalam memberikan penyuluhan dan pendampingan literasi informasi. Tim mengidentifikasi anggota mitra kelompok sasaran termasuk mediapeliputan

3. Tahap Ketiga

Pada tahap ini, tim menyusun panduan teknis kegiatan dan menentukan waktu pembekalan materi literasi informasi kepada peserta mahasiswa secara online menggunakan aplikasi zoom dan whatsupp group yang telah dibeetuk dan dipersiapkan. Pada tahap ini juga tim bersama peserta akan mendesain poster, gambar dan vidio serta TOR (term of references), selektivitas berita sehingga memudahkan mitra memahami maksud, tujuan, ciri, jenis dan bentuk jurnalisme harapan yang dilaksanakan.

4. Tahap Keempat

Tahap ini merupakan tahap pelaksanakan kegiatan lapangan, dimana seluruh rencana, peserta dan lembaga mitra termasuk kebutuhan yang diperlukan telah dipersiapkandan dengan baik. Pelaksanaan kegiatan akan dilakukan secara online menggunakan aplikasi zoom dan whatsupp group yang sengaja dibentuk, baik kepada peserta maupun mitra kegiatan sebagai kelompok sasaran yang dituju. Dosen akan memberikan materi kepada kelompok sasaran dalam hal ini mitra kegiatan yang dibantu oleh mahasiswa dalam bentuk totorial, desain gambar, vidio dan dokumen.

2. Rekruitmen Peserta

Rekrutmen peserta KKN tematik terintegrasi pengabdian dosen, akan dilakukan secara terbuka dan transparan kepada mahasiswa. Persyaratan peserta yang dapat 
mengikuti kegiatan ini adalah mahasiswa yang memiliki kelayakan akademik berupa, IPK. 3.00 keatas, jumlah SKS lulus, tahun semester dan kecakapan teknis menyusun literasi informasi pada media. Selain itu, peserta yang telah dinyatakan lolos diwajibkan mengisi kesedian peserta yang diketahui orang tua mahasiswa.

\section{PembekalanMahasiswa}

Pembekalan mahasiswa peserta KKN Tematik bertujuan untuk memberikan pengayaan dan pemahaman dasar terkait dengan program kerja, fokus, dan sasaran program yang akan dicapai pada kelompok sasaran yang dituju. Pembekalan kegiatan akan dilakukan secara online melalui aplikasi zoom dan whatsapp group yang telah dipersiapkan selama 2 (dua) hari kerja dengan durasi 120 menit, secara berturut-turut. Pembekalan direncanakan berlangsung dalam 2 (dua) tahap, yakni;

1. Tahap pertama, Pembekalan kegiatan terdiri dari materi umum dan materi khusus tentang jurnalisme harapan yang terdiri dari ciri, jenis dan bentuknya serta mekanisme penyebarannya dalam masyarakat.

2. Tahap kedua, selanjutnya tim akan membuat pemetaan informasi tersebut berdasarkan ciri, jenis dan bentuknya untuk bahan penyuluhan ke kelompok sasaran (kelompok pemuda/karang taruna) dalambentuk teks, gambar, poster danvideo.

\section{Lokasi KKN-Tematik danSasaran}

Kegiatan Program Pengabdian Masyarakat terintegrasi KKN-Tematik akan dilaksanakan secara online berdasarkan lokasi alamat para peserta mahasiswa dan mitra yang dipilih masing- masing di kelurahan yang ada di Kota Kendari.

Sasaran kegiatan ini adalah kelompok karang taruna di tingkat kelurahan/desa, dalam bentuk penyuluhan dan pendampingan selektivitas jurnalisme harapan informasi covid-19 di Kota Kendari. 
Pelaksanan kegiatan Pengabdian kepada Masyarakat Terintegrasi KKN Tematik akan dilaksanakan pada hari sabtu dan minggu selama 25 hari kerja.

\section{B. HASIL DAN PEMBAHASAN}

Berdasarkan Program Kinerja KKN Tematik diatas, berikut Hasil kinerja yang telah dicapai:

1. Pengumpulan nomor handphone WhatsApp masyarakat khususnya Karang Taruna yang ada di Desa/Kelurahan Kota Kendari.

Hal atau kegiatan pertama yang dilakukan pada saat KKN Tematik di Kelurahan yang ada di Kota Kendari yakni mengantar surat izin ke kantor Desa/Kelurahan yang kemudian diteruskan dengan memberikan informasi seputar rencana kegiatan selama masa KKN Tematik dan salah satu informasi yang disampaikan yakni terkait Pembuatan WhatsApp Group masyarakat di Kelurahan tersebut dan langkah yang akan ditempuh sebelum dibentuknya group informasi tersebut.

Ada beberapa cara yang dilakukan pada saat melakukan pendataan nomor Handphone untuk WhatsApp Group, yakni dilakukan secara tatap muka langsung yakni pada saat menyebarkan kuisioner, pada saat sosialisasi secara face to face, sosialisasi seputar lingkungan RT maupun langsung menghubungi pihak RT dan RW agar meminta data dan juga nomor HP masyarakat yang dijadikan sasaran untuk bergabung dalam Group WhatsApp Informasi seputar Covid-19 yang sudah dibuat oleh Mahasiswa Tim KKN Tematik 2020. Pengumpulan Nomor Handphone ini dilakukan secara langsung dengan tetap mematuhi protokol kesehatan. Setelah dilakukan pendataan tersebut, maka dibentuklah Group WhatsApp, tempat menyebarkan dan saling bertukar informasi. 
Gambar 1. Pengantaran Surat Di Kelurahan dan Pengumpulan Nomor Handphone Whatsapp Masyarakat Khususnya Karang Taruna yang Ada di Desa/Kelurahan Kota Kendari.
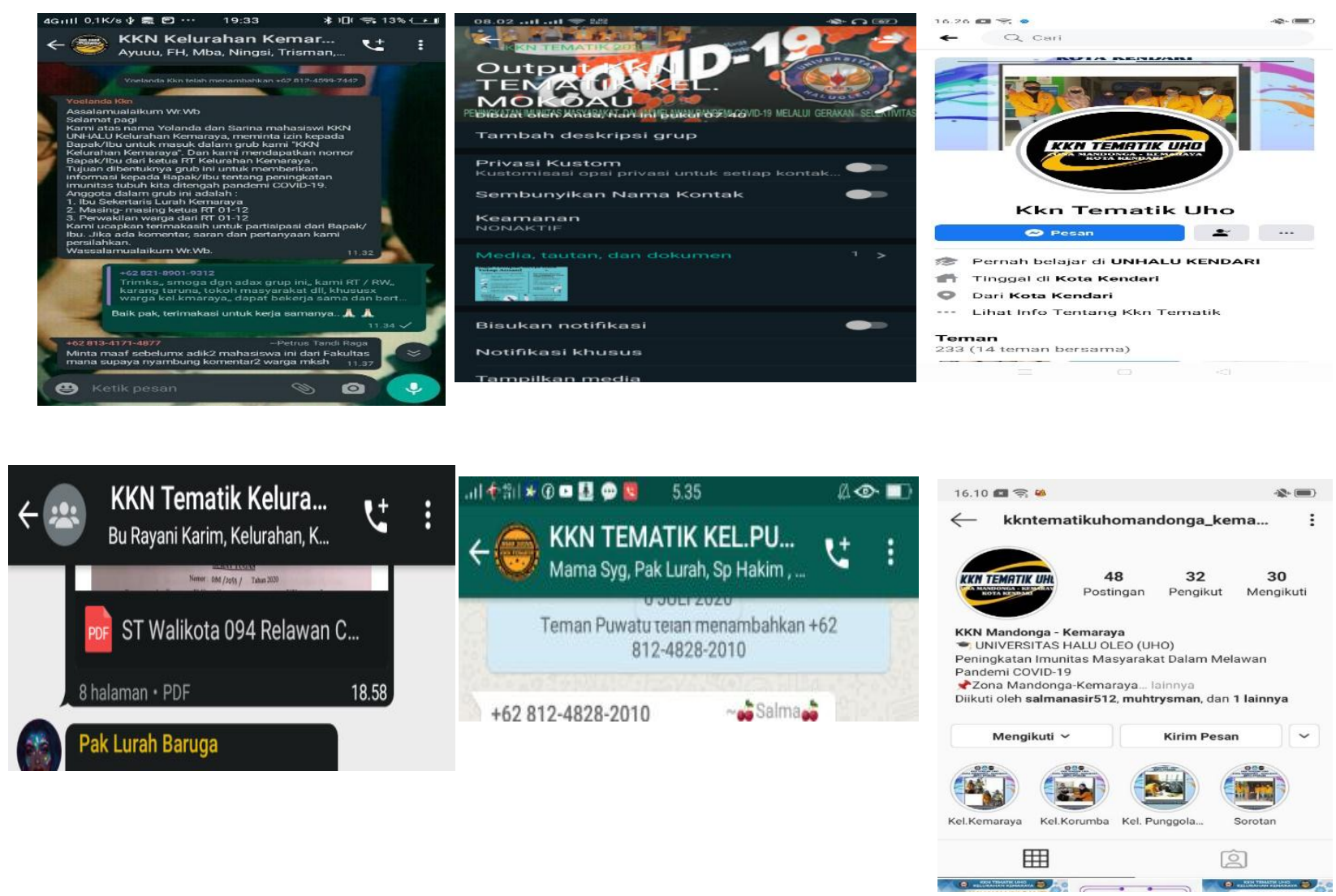

Gambar 2. Group WhatsApp dan Media Sosial lainnya yang sudah dibentuk 2. Membuat dan menyebarkan kuesioner untuk mengukur tingkat pemahaman dan pengetahuan, sikap dan tindakan masyarakat terkait pandemi covid-19.

Kuesioner ini dibuat dengan teknis analisis menggunakan analisis data kuantitatif melalui sampel data kuesioner yang diperoleh, dalam hal ini responden yakni 
masyarakat di Kelurahan tersebut, demi mengukur tingkat pemahaman, sikap dan perilaku/tindakan masyarakat setempat terhadap bahaya dan hal-hal lain seputar covid-19. Cara pengambilan sampel atau pemilihan orang sebagai sampel dilakukan secara proporsional artinya minimal ada keterwakilan kelompok umur, jenis kelamin, dan pendidikan berdasarkan petunjuk kuesioner yang diberikan. Setelah melakukan pendataan dengan cara menyebarkan kuisioner kepada masyarakat dari minggu pertama hingga selesai, diperoleh data gambaran bahwa tingkat pengetahuan dan pemahaman masyarakat di Desa/Kelurahan yang ada di Kota Kendari yakni memiliki pemahaman yang sama, yakni tahu tentang covid-19, namun tidak secara menyeluruh dan mendasar, meskipun dilihat dari segi umur, usia dan pendidikan yang berbeda. Dari data gambaran tersebut, sehingga Tim KKN Tematik mengadakan sosialisasi lebih detail khususnya pada akun media sosial yang dibuat, untuk menyebarkan informasi tentang hal-hal yang mendasar dari covid-19, terutama terkait peningkatan imun tubuh yang selain dari makanan juga dari konsumsi bahan bacaan/informasi tentang covid-19.

3. Melakukan sosialisasi secara langsung yang dirangkaikan dengan pembagian masker kepada masyarakat di wilayah seputar RT dengan tetap mematuhi protokol kesehatan dan juga secara face to face dan door to door kerumah warga. Proses selanjutnya yakni dengan melakukan Sosialisasi kepada masyarakat secara langsung dengan tetap menjaga protokol kesehatan. Sosialisasi yang dilakukan diantaranya secara face to face dan door to door ke rumah warga (namun tidak semua) dan juga sosialisasi di sekitaran lingkungan RT sekitar Kelurahan, menyebarkan kuisioner sekaligus memberikan informasi kepada masyarakat tentang hal-hal yang perlu dilakukan untuk membangun system imun yang baik untuk melawan covid-19 dalam bentuk brosur dan sejenisnya serta memberikan masker kepada masyarakat. Sosialisasi secara langsung tidak terlalu rutin dilakukan mengingat harus tetap waspada menjaga jarak dan menghindari kegiatan yang melibatkan orang banyak. Sehingga hal lain yang dilakukan yakni menyebarkan brosur ke fasilitas umum seperti Masjid dan lain sebagainya dan 
selebihnya dilakukan secara online dengan memanfaatkan media sosial yang sudah dibuat.
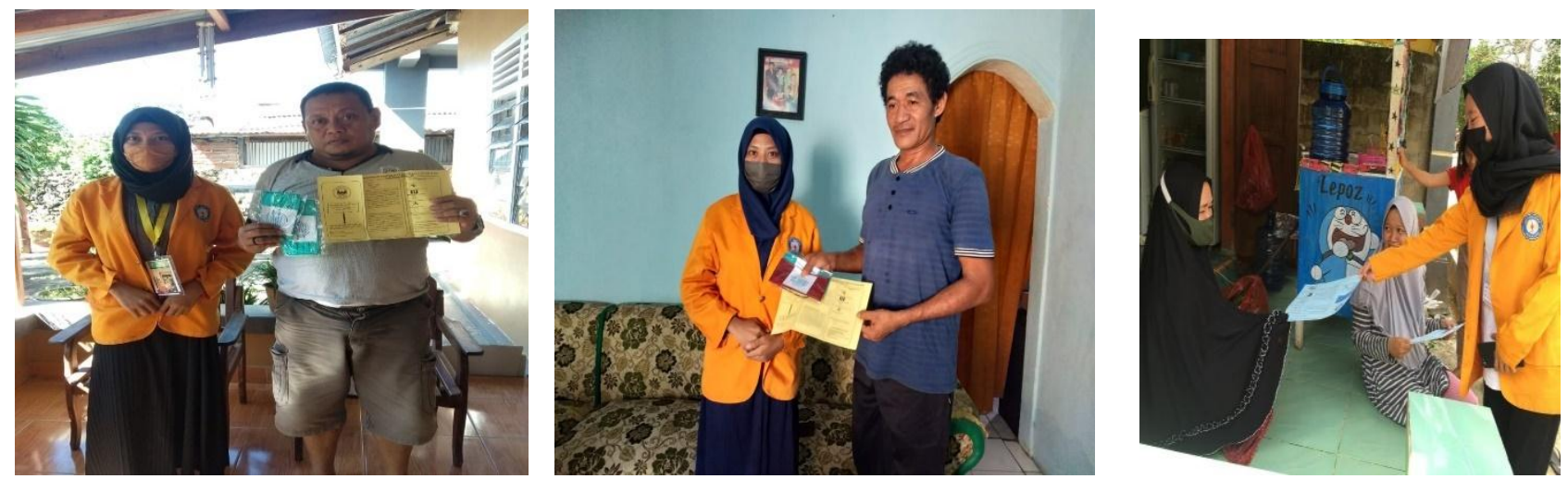

Gambar 3. Penyebaran Kuisinoner, Pembagian Masker dan Sosialisasi Secara Langsung

4. Melakukan Sosialisasi secara tidak langsung dengan menggunakan media sosial Whatsapp (Group yang sudah dibentuk), media sosial Instgaram dan Facebook yang dibuat untuk mempermudah menyebarkan informasi positif kepada masyarakat. Sosialisasi Online, menyebarkan berita/informasi via online yang dilakukan secara rutin oleh Tim KKN Tematik Kelurahan di Kota Kendari, (Terutama di WA Group Masyarakat). Berita/informasi/liflet/brosur/ yang akan dibagikan akan diselesksi terlebih dulu agar bisa dipastikan apakah berita tersebut bukan berita yang bersifat hoax. Penyeleksian berita ini akan dilakukan pertahap agar berita yang di baca masyarakat tidak menimbulkan kesimpang siuran. Dimana sekarang banyak dari orang-orang yang tidak bertanggung jawab membagikan berita yang sifatnya hoax kepada masasyarakat sehingga masyarakat merasa cemas apalagi dengan yang sekarang ini dengan adanya pandemi Covid-19 ini. Brosur atau liflet atau pamflet yang disebarkan juga berisi konten positif untuk meningkatkan imun tubuh. Selain disebarkan di W Group, infonya juga disebar ke akun media sosial yang sudah dibentuk oleh Tim KKN Tematik yakni di Media Sosial Instagram dan Facebook, agar dapat diakses dan oleh siapa saja. 


\section{KESIMPULAN}

Berdasarkan hasil Pengabdian Kepada Masyarakat Dosen Terintegrasi Kuliah Kerja Nyata (KKN) Tematik Universitas Halu Oleo (UHO) Tahun 2020 tentang Peningkatan Imunitas Masyarakat Dalam Melawan Pandemi Covid-19 Melalui Gerakan Selektivitas "Jurnalisme Harapan" Pada Media Daring Dan Media Sosial Di KotaKendari, dapat di tarik kesimpulan bahwa masyarakat yang ada di wilayah Desa/Kelurahan yang ada di Kota Kendari sesuai dengan Program Kerja yang disudah terapkan selama melakukan KKN Tematik yang mungkin juga sedikit terkendala dengan waktu dan kegiatan dari masyarakat sekitar ditengah pandemi covid-19, mulai dari kegiatan mengumpulkan nomor handphone masyarakat sekitar melakukan sosialisasi secara langsung dengan tetap mematuhi protokol kesehatan dan juga membagikan kuisioner untuk melihat perilaku dan pengetahuan masyarakat tentang covid-19 hingga tahap akhir dengan membentuk group dan melakukan sosialisasi online di group yang sudah dibuat dan akun media sosial lainnya yakni berjalan dengan baik, masyarakat masih terkategori pada tataran yang terbilang masih efektif artinya sikap masyarakat setelah wadah edukasi dari pengabdian ini, tentu melahirkan antusias tetap taat terhadap protokol kesehatan dan peningkatan imunitas tubuh.

\section{UCAPAN TERIMA KASIH}

Persembahan syukur dan terimakasih yang paling tertinggi di haturkan kepada sang Pencipta Tuhan Yang Maha Esa karena atas kehendakNya dan perlindunganNya sehingga seluruh rangkaian kegiatan pengabdian terintegrasi KKN Tematik tahun 2020 dapat berjalan dengan baik dan lancar.

Ucapan terimakasih yang tak terhingga kepada Lembaga Penelitian dan Pengabdian Universitas Halu Oleo atas dukungan dana dan kesempatan yang diberikan kepada Tim sehingga kegiatan ini dapat memberikan manfaat kepada masyarakat khususnya dalam mengatasi pandemic covid 19.

Kepada seluruh anggota TIM yakni dosen pembimbing serta mahasiswa peserta KKN Tematik yang telah berjuang di lapangan meski dalam situasi yang menghawatirkan untuk kesehatan dan keselamatan diri dari virus covid 19 namun tetap berkarya dan 
memberikan manfaat yang positif kepada masyarakat di haturkan terimakasih dan penghargaan yang setinggi tingginya.

Tak lupa untuk masyarakat Kota Kendari dan seluruh pihak yang turut ambil bagian di berbagai kelurahan tempat pelaksanaan kegiatan pengabdian ini berlangsung ucapan terimakasih yang tak terhingga atas partisipasinya dan kepatuhannya dalam menjalankan protokoler kesehatan serta mendukung terlaksananya kegiatan pengabdian ini. Semoga apa yang telah TIM Pengabdian lakukan akan memberikan manfaat kepada masyarakat dalam menghadapi pandemic covid 19 dengan hati dan pikiran yang bahagia, penuh harapan dan terhindar dari segala kecemasan.... Amin.

\section{DAFTAR PUSTAKA}

Badan Pusat Statistik (BPS) Kota Kendari. Diakses dari https://kendarikota.bps.go.id/, diakses pada tanggal 10 September 2020 pada jam 06.30 WITA.

Badan Pusat Statistik (BPS) Kota Kendari. "Kota Kendari Dalam Angka 2019". Katalog BPS Kota Kendari 1102001.7471 diakses dari https://kendarikota.bps.go.id/, diakses pada tanggal 10 September 2020 pada jam 06.35 WITA. 